\title{
Solvothermal synthesis of chitosan quantum dots using different solvents
}

\author{
RAMENDRA SONI*, UNNATI SONI ${ }^{1}$, BHAVANA TANDON, ASHISH KUMAR AND SANDEEP KUMAR
}

Department of Molecular and Cellular Engineering, Sam Higginbottom Institute of Agriculture, Technology and Sciences, ALLAHABAD (U.P.) INDIA

${ }^{1}$ Ewing Christian College, ALLAHABAD (U.P.) INDIA

\section{ARITCLE INFO}

Received : 29.01 .2016

Accepted : 25.03 .2016

\section{KEY WORDS :}

Quantum dots, Hydrothermal, Solvothermal, Salicylic acid, 5-

Sulphosalicylic acid

*Corresponding author:

Email: ramendra.r.soni@gmail.com

\section{ABSTRACT}

In this current research, carbon quantum dots were synthesized by solvothermal synthesis method, using different solvents. The different solvents which were used for synthesis of carbon dots were 5-Sulphosalicylic acid, and Salicylic acid.In this method 1 per cent salicylic acid and 2 per cent 5 -Sulphosalicyic acid was used with ethanol in hydrothermal bomb for 4 hours at $140^{\circ} \mathrm{C}$. After the synthesis period a luminescence was seen with both the solvents. The solvents produced green, violet and blue fluorescence at different wavelengths of UV light.

How to view point the article : Soni, Ramendra, Soni, Unnati, Tandon, Bhavana, Kumar, Ashish and Kumar, Sandeep (2016). Solvothermal synthesis of chitosan quantum dots using different solvents. Internat. J. Plant Protec., 9(1) : 333-336. 